\title{
Negras narrativas de Guaianases: Memórias não expropriadas.
}

\author{
Sheila Alice Gomes da Silva ${ }^{1}$
}

Resumo: Resultado das discussões engendradas para a composição da dissertação de mestrado intitulada: "Negros em Guaianases: Cultura e Memória", o texto do presente artigo ancora-se no conceito de micro-Áfricas e na metodologia da história oral, especificamente na história de vida, para confrontar a ideologia eurocêntrica hegemônica que fundamenta as histórias popularizadas sobre Guaianases e perceber a presença e as manifestações de resistência dos grupos negros moradores do bairro. Evidenciando uma das entrevistas realizadas para a pesquisa foi possível aperceber-se, a partir da narrativa de dona Penha Maria Lima Severino, a difusa e resistente presença desses grupos outrora invisibilizados.

Palavras-Chave: Guaianases; Grupos negros; Micro-áfricas; história oral.

Abstract: Discussions of the results engendered for the composition of the dissertation entitled " Blacks in Guaianases: Culture and Memory" of this Article text anchored in the concept of microAfricas and methodology of oral history, specifically the history of life, to confront the hegemonic Eurocentric ideology that underlies the stories popularized on Guaianases and realize the presence and resistance manifestations of black residents of the neighborhood groups. Showing one of the interviews conducted for the study, it was possible to realize, as Maria da Penha Lima Severino owner of narrative, diffuse and strong presence of these groups once invisible.

Keywords : Guaianases; Black Groups; Micro-Africas; oral history.

\section{Introdução}

Guaianases é atualmente um bairro com aspirações de cidade. Não só pela área geográfica e pelo índice demográfico ${ }^{2}$, mas também pela pluralidade cultural que permeia o cotidiano de seus habitantes. Mesmo assim, é uma história eurocentrada e hegemônica que, ainda, impregna a memória coletiva dos habitantes do bairro. Uma história que representa e reproduz o discurso popularizado no final do século XIX pelas elites intelectuais, que apontava para uma idealização identitária onde a nação brasileira ${ }^{3}$ precisaria promover o branqueamento de sua população para se tornar civilizada. A cultura européia não ocupa apenas o lugar de destaque no contexto de fundação e urbanização do bairro, mas se coloca como sua própria identidade.

A perpetuação de uma história hegemônica que impregnou a memória popular

1 Doutoranda em História Social pela PUC-SP e pesquisadora do Centro de Estudos Culturais Africanos e da Diáspora. E-mail: sheilagomessilva1@gmail.com .

2 Segundo os índices apontados pelo Censo do ano de 2010 realizado pelo Instituto Brasileiro de Geografia e Estatística (IBGE), o bairro de Guaianases compreende uma área geográfica de 17,8 Km² e uma população de 283.162 habitantes.

3 Utilizamo-nos da terminologia nação nessa parte do texto apontando para a ideologia dominante propagada pelos intelectuais a partir de meados do século XIX, mas entendemos que o conceito de nação produz um Brasil europeu, a morte da memória, legitimando uma padronização étnica, conforme salienta Risério (2007). 
coletiva representou em larga escala um esforço para invisibilizar as culturas e experiências negras constituídas na relação com o território. Mesmo assim, não foi capaz de encerra-las. Os grupos negros moradores do bairro de Guaianases ainda se fazem presentes, numa resistência progressiva, espalhados por diversos espaços da região, mas unidos pelo lugar da perpetuação das memórias negras.

Ao olhar para o tecido urbano da cidade de São Paulo o historiador Azevedo (2006) percebeu experiências concretas e históricas que não se deixaram apagar diante de uma racionalidade elitista moderna. Essas manifestações emergiram e/ou emergem em resposta aos processos impostos de urbanização e metropolização, também, expressas em “[...] traços específicos da cultura dos grupos, nos costumes, nos gestos, nos cantos e nos territórios apropriados [...]" (IBID, p.23). Conformadas para além do plano das ideias assumem, sobretudo, múltiplos sentidos reconhecedores dos modos negro-africanos, característicos, de pensar e estar no mundo que penetraram copiosos fazeres e saberes da vida cotidiana dos grupos negros na cidade, e foram denominadas pelo autor como micro-Áfricas.

Múltiplas, as micro-Áfricas constituíram-se a partir de "[...] grupos afros em determinados espaços sociais onde tiveram que reagrupar e redefinir práticas culturais herdadas dos descendentes de africanos diante do processo de urbanização da cidade de São Paulo.” (AZEVEDO, 2006, p.34). São verdadeiros territórios de resistência na "[...] luta para preservar e ressignificar suas expressões culturais [...]" (IBID, p.34), que insubmissos desobedecem "[...] limites estabelecidos do que deveria ser a cidade [...]" (IBID, p.34), produzindo "[...] formas de sociabilidade e sensibilidade que expressam a cultura dos afro-paulistas de modo difuso [...]" (IBID, p.24), mas também de outros grupos negros alocados na urbe. Pensar em micro-Áfricas é também desprender-se de lentes singularizadoras e homogeneizadoras das experiências culturais dos grupos negros, olhar suas miudezas e conclamar suas multiplicidades. Entendendo que estas nos possibilitam pensar e compreender as resistentes memórias negras do bairro de Guaianases, no desafio da busca por pormenores, o comumente despercebido, as micro conjunturas, o simples, o corriqueiro, o que é aparentemente desimportante, mas capaz de lançar luzes sobre as profundezas do viver, tomamo-las como conceito norteador.

Escolhemos, portanto, olhar para lugares culturais onde esses grupos negros fossem entendidos enquanto agentes de suas culturas e histórias, onde suas praticas buscassem reafirmar África em seus saberes e na constituição de suas relações, para percebermos as estratégias que perpassam seus lugares de enunciação, suas articulações e as maneiras que se fazem ouvir. E, a 
partir, das micro-Áfricas apreender as maneiras pelas quais descontroem retóricas universalistas, valorizam o local, confrontam epistemologias consagradas e se auto representam. Sendo assim, identificar micro-Áfricas nesse universo bairrista é, também, pensar movimentos engendrados pelos grupos negros de Guaianases na luta contra o apagamento de suas memórias da história popularizada, reconhecer o pertencimento destas comunidades no território, as lutas pela sobrevivência, para educar os filhos, manter a coesão familiar e constituir o lar. Entendendo-as como o lugar da memória viva que se dá na experiência social, acessa-las representa a oportunidade de perceber o redimensionamento dos traços negro-africanos nos modos de ser e estar desses grupos, e de também, recompor essas memórias negras latentes em Guaianases.

Como estratégia para acessar e captar tais memórias, compostas nas experiências vividas - sentidas, nos aproximamos da tradição oral que na palavra liga-se a dimensão espiritual, vibra forças divinas, compondo a força vital das sociedades africanas, e assumindo seu lugar de fonte primeira do conhecimento, Hampaté Bâ (2010). No Brasil é possivel reconhecer sinais dessas tradições africanas, uma ascendência escancarada pelo modo de narrar, memorizar e de se fazer das culturas negras, como evidencia Antonacci (2013). Mais especificamente, escolheu-se a metodologia da história oral que se dedica a registrar as narrativas das experiências humanas de sujeitos, até então, anônimos nas histórias universalistas, para abrir as janelas propostas por Antonacci (2013), em paredes tão bem concretadas pelo tempo, pelo sistema de ensino ocidental e um conjunto de valores cartesianos. “[...] a história oral se assenta na voz [...] suas fontes são agentes históricos e não documentos distantes; concepções de tempo, trabalhos de vocalidade e memória, territórios de subjetividade e performances corporais tornaram-se questões emergentes [...]" (IBID, p.30). Segui-la implica segundo Vansina (1982) na assunção de uma atitude que valoriza um tipo de experiência comumente ausente na historiografia tradicional para ter contato com valores profundos e sabedorias ancestrais, privilegiando cognições que se organizam a partir da oralidade.

Mesmo nos apresentando inúmeras possibilidades de ação, em Souza (1995) entendeu-se que as fontes orais por si próprias não detêm o poder de produzir uma contra história, ainda que estiverem transcritas nestas as narrativas oralizadas fidedignamente. $\mathrm{O}$ autor aponta a necessidade maior de se "[...] superar pressupostos da linearidade, dos determinismos, trabalhando criticamente com as fontes [...]", para que estas fontes possam constituir-se como um "[...] recurso para cobrir lacunas dos arquivos escritos." (IBIDEM, p.20), o que vai requerer dos (as) historiadores (ras) profundas análises, uma busca por atribuir sentido ao que se ouve e contextualizações diversas. 
Ademais, cabe salientar que, manter-se com os sentidos atentos foi o que me permitiu como pesquisadora alcançar as subjetividades apontadas por Portelli (1993) alocadas nos entrelinhas que permeiam as narrativas das histórias vividas, trazendo a sociedade para o debate acadêmico, uma das façanhas empreendidas pela história oral.

Segundo Hall (2013) ninguém escapa das formas de representação social, e nisso se aloca um grande desafio, o de buscarmos as autorrepresentações, afinal todos têm o direito de acessar memórias formadoras de suas identidades. Desse modo, procurou-se constituir uma relação empática e afetiva para abertura das memórias, como observamos em Bosi (1994), e passemos a entender o entrevistador e os entrevistados, como coniventes. Um entrevistador que se aproxime dos dramas, dores e alegrias narradas, sem perder de vista a preocupação social e acadêmica, assumindo um papel de mediador nessa relação, e o entrevistado como colaborador que a partir de suas memórias leva o entrevistador a pensar novas questões da pesquisa. Entende-los dessa forma é tecer uma relação mais humanizada, onde o colaborador jamais é entendido como o objeto da pesquisa. Suas narrativas constituem-se em fontes orais e, portanto, o elemento imprescindível e central para as reflexões deste trabalho, como aponta Souza (1995) quando busca apreender os significados da experiência humana dos sujeitos ocupantes de terra e suas lutas por moradia na periferia da Zona Leste de São Paulo.

\section{Memórias negras narradas}

Ancorados em saberes da tradição oral e na oralidade como recurso de veiculação, é por meio dessa tradição viva que compreendemos ser possivel apreender as memórias negras do bairro. Como aponta a professor Bosi (1994) quando entende as lembranças como verdadeiros mecanismos reveladores de passados, entendeu-se que os recursos das entrevistas com sujeitos negros emblemáticos para história de Guaianases nos possibilitariam identificar diferentes formas de perceber o mundo e outras representações sobre o bairro que contemplariam relações sociais e raciais bastante peculiares. Por isso, escolheram-se particularmente as histórias de vida para perceber práticas cotidianas comuns, táticas e estratégias em prol da sobrevivência, da constituição de relações entre os sujeitos que emanam um potencial enunciativo como observa Certeau (1982), que nos auxiliaram a reconstruir outro olhar, a partir de vozes que, ainda, não haviam sido ouvidas.

A partir do exercício da escuta de quem fala, a escuta do outro, característica marcante em Certeau (1998), e que se da como um processo de busca para entender a alteridade, e perceber sujeitos que se estabelecem pela palavra. Assim como as velhas tecedeiras de colchas de retalhos, que habitam minhas lembranças infantis, acolho fragmentos das falas de uma negra moradora do 
bairro de Guaianases, tendo como elo entre suas histórias a palavra, para que se possa escrever memórias. São histórias locais que reconhecem no colaborador o sujeito, pois estas só acontecem por ele, independente de sua classe social, nível de escolarização ou etnia, o ambiente do aprendizado se torna o mundo. Entendendo que a história universalista é incapaz de representar a todos, mas havia, até então, conseguido se impor sem abrir precedentes e possibilidades de argumentação com outros pontos de vista. Sendo assim, colocamos em relevo as histórias particulares, àquelas que não se deixaram calar, não foram anuladas, resistiram e estão cheias de significados.

E é a partir da história oral de vida, onde as narrativas tem feições biográficas, seguiu-se com uma entrevista aberta, com o mínimo de interferência da mediadora, conforme sugere o professor Meihy (2005). O que significou reconhecer na liberdade do falar um fator de humanização de um processo historiográfico que se alarga, mas também, se aproxima de seus sujeitos quando registra a experiência de homens e mulheres. "A exposição oral de um tema retira o autor do isolamento da escrita. [...] durante uma entrevista, não se quer ler um texto, quer ouvir; não quer a letra, quer a fala” (D`ALESSIO, 2001, p.69). Fala esta, que teve como meio de coleta um gravador, usado no objetivo de registrar, preservar e descentralizar o uso e a produção das memórias, tornando esta uma oportunidade de acessar as relações entre o local e o global, abrindo as experiências e memórias negras de Guaianases para o mundo. O que representa o possivel alcance de uma produção cientifica.

Sobre o caminho escolhido de abordagem do sujeito para motivar ou desencadear o processo de rememoração, seguimos as pistas e apontamentos deixados por Bosi (1994), quando evidencia a necessidade de se adotar uma aproximação não direta, diversificada e afetiva, e Le Goff (2003) que percebe as fotografias familiares como proporcionadoras de uma revolução nos processos de memória, quando “[...] evocam e transmitem a recordação dos acontecimentos que merecem ser conservados." (IBID, p.402). Sendo assim, usamos as fotos antigas da própria colaboradora como elementos de aproximação e suportes acionadores de "memórias adormecidas" (Bosi, 1994). Entre uma foto e outra, foi possivel adentrar em experiências profundas como as de Dona Penha Maria Lima Severino, que se fosse música se chamaria Samba.

Uma combinação de cavaquinho, pandeiro, surdo, cuíca, tamborim, repique e um canto inflamado, não poderiam faltar em nossa conversa, já que Dona Penha iria ali expressar sua história de vida nenhuma outra trilha sonora contribuiria mais para o exercício do lembrar. Mulher negra, de 57 anos, nascida na mesma casa no bairro em que morou até se casar com 19 anos, diz com orgulho 
que nunca saiu de Guaianases. Nossos diálogos se deram em sua casa, espaço que seria facilmente confundido com um barracão de escola de samba, uma associação ou um bar de amigos. Cada parede é adornada de modo diferente, são fotos, quadros e penduricalhos diversos espalhados por um vermelho alegre.

Filha de Agostinho Cassiano de Lima, pedreiro, e Teresinha Rodrigues de Lima, doméstica, migrantes de Minas Gerais, da cidade de Guapé, chegaram ao bairro procurando melhores condições de vida.

Meu pai e minha mãe foram uns dos fundadores de Guaianases. Não sei ao certo o ano que chegaram aqui, mas meu irmão de 68 anos já nasceu aqui, e meus pais já viviam aqui. Meu pai construiu quase todas as casas de Guaianases na época.

Ao falar de seus progenitores, dona Penha reivindica um papel de fundadores a eles, o que representa reconhece-los como protagonistas das histórias de criação do bairro. Rememorar o pai como construtor das casas do bairro é também dizer que o papel de fundador não está contido e finito no ato de chegar ao território e passar a fazer dali seu lugar, mas materializou-se, tomou concretude numa prática construtora, que deu formas, contornos e proporcionou vida àquele bairro. Além disso, ela ainda sugere um deslocamento da percepção comum sobre os serviços braçais, sempre associados a inferiorização dos sujeitos fazedores, para imputar a este um título de construtor, e mais que isso, o fundador.

Tendo em mãos uma de suas fotos em preto e branco, em que estavam ela, seu pai, mãe, primas e tio dentro da gruta da Igreja São Benedito, onde está alocada a imagem do padroeiro do bairro, relata que durante a sua infância frequentava dominicalmente aquela igreja, também edificada por seu pai.

Naquela época o mutirão de construção da igreja era meu pai, o seu Vicente, o seu Emilio, o José [...] e todas as pessoas, eram quase todas negras. Naquela época tinha bastante negro na São Benedito, eram fiéis a São Benedito. Mesmo os poucos brancos que tinha, viviam mais ali no meio da negrada.

Ao rememorar uma comunidade de fiéis majoritariamente negra, que conformava a membrezia da igreja no período de sua construção, fornece pistas para dentro da conversa sobre um elemento bastante importante para pensarmos um bairro que desde os primórdios tem sido representado como branco-europeu, mas escolheu para si um padroeiro preto.

Situada às portas de entrada do bairro, a Paróquia São Benedito, foi fundada oficialmente no ano de 1940, sobre um terreno doado pelos proprietários: o senhor Benedicto Leite de Ávilla e sua 
esposa, dona Antônia Cardoso Leite, imigrantes portugueses, à Mitra Archidiocesana de São Paulo no ano de 1932, que valia cerca de quinhentos mil réis, conforme escritura de doação registrada no Cartório Masagão de São Paulo. Esse episódio conferiu grande prestígio ao doador, uma vez que o mesmo é, por vezes, rememorado como o real motivo pela escolha de seu homônimo padroeiro, São Benedito $^{4}$. E essa é uma questão que nos chama a atenção, especialmente quando em busca de uma chave interpretativa enquanto possibilidade de entender esse processo de nomeação, podemos dialogar com Holanda (1995), que percebe no brasileiro uma acentuada afetividade, sinalizada dentro da religião e dos ritos católicos conformados no Brasil numa prática cordial, mais humanizada, carinhosa, propositora de maior intensidade, intimidade. Para o autor, o brasileiro propõe um relacionamento de familiarização com as divindades, facilmente observado pelo exemplo citado por ele sobre Santa Teresa de Lisieux, chamada no país de Santa Teresinha.

A adoração aos santos é composta por uma acentuada dimensão afetiva baseada numa proximidade, uma paixão devocional por seu padroeiro que, então, relativiza e propõe a necessidade de uma interpretação que vá além da homenagem da figura em si. Nisso, é possivel entender que uma comunidade não escolheria um padroeiro sem manter com ele toda uma relação de afetividade e fé. E o fato de haver um padroeiro negro na igreja matriz de Guaianases é muito significativo a fim de perceber a presença de uma memória negra naquele lugar. $\mathrm{O}$ que significa pensar que não só o catolicismo sofreu um enegrecimento desde o século XVIII, como cita Mattos et al (2014), com as muitas conversões de africanos e afro-brasileiros, como é possivel também considerar uma relação dialógica, na qual há um "empretecimento" ou uma africanização de brancos que cultuam um santo negro, apropriando-se desses signos culturais. O preto no branco e o branco no preto. De um lado uma marcha que repele, nega e invisibiliza, e do outro um movimento que revela a força das culturas negras penetrando, transpondo, invadindo, entranhando-se $\mathrm{s}^{5}$

Eu sou nascida e criada em Guaianases, nunca saí! [...] temos muitas famílias antigas aqui, como os Gianettis, mas só que eu acho que as pessoas se esquecem das outras famílias que veio. Eles colocaram as famílias ricas, mas não colocaram as famílias pobres. Porque se você vê em Guaianases,

4 Informação captada em conversa informal com a atual secretaria da paróquia, a Sra. Joana (nome fictício), em 15 de setembro de 2015, e também com Roberto (nome fictício), funcionário administrativo, responsável pela organização da história da instituição no bairro, em 14 de setembro de 2015.

5 Cabe salientar que apesar de inúmeros contatos feitos com a administração da igreja local, a Diocese de São Miguel e a Arquidiocese de São Paulo, constatou-se a ausência de documentos que pudessem nos auxiliar na busca por dados demográficos sobre a comunidade religiosa do período da sagração. Mesmo podendo contar com uma produção historiográfica recente que tem se aprofundado no estudo das igrejas que se constituíram em devoção a santos (as) negros (as), organizadas por grupos negros em forma de irmandades na busca pelo reconhecimento de seu protagonismo na construção da cidade de São Paulo e na preservação de suas histórias, culturas e identidades, não houve qualquer possibilidade de afirmar, com relação à Paróquia São Benedito, semelhante movimento de constituição, sem fazer ilações, por falta de documentação que nos indicasse tal realidade. 
você vai achar a família Bonfim, antiga, ninguém fala deles. A família Lima, que é a minha família, os Senhas, somos famílias antigas, mas eles nunca vieram para conversar com a gente, só coloca os Matheus, dizendo que fizeram melhorias pro bairro. Mas o meu pai também fez, e aí?! Meu pai trabalhava de pedreiro, na chuva e no sol. O seu Vicente ${ }^{6}$ também fez e ele também é esquecido. O seu Emilio [...] então, tem um monte de negros que ninguém se lembra. Essa história de Guaianases que hoje todo mundo pinta, na realidade não é isso!

Num discurso bastante lúcido e militante, ela coloca em relevo uma crítica às histórias popularizadas no bairro que constroem uma memória branca e imigrante em detrimento da forte presença negra em Guaianases. Reconhece outras famílias negras que igualmente participaram dos processos de melhoria para a área, e reivindica a participação destes trabalhadores que não eram donos dos meios de produção, mas compartilhavam dos trabalhos.

Minha vó Maria foi uma das primeiras parteiras do bairro, fez quase todos os partos aqui do bairro e ela não cobrava nada de ninguém. A gente não tinha hospital, os partos eram feitos tudo em casa. Quando ela faleceu eu tava com 6 anos.

A memória de sua avó parteira reafirma uma função que aparece de maneira recorrente nos registros de nascimento compostos no cartório de Guaianases entre os períodos de 1930 e 1960, cuja nossa pesquisa dissertativa, disposta em Silva (2015), debruçou-se de maneira sistemática. Assim como os nascidos, seus progenitores e avós, essa documentação evidenciou personagens de grande importância para se pensar o crescimento demográfico e os sujeitos do bairro naquele tempo-espaço, as parteiras. Os registros em geral apontam nascimentos feitos em domicílios, o que marca a presença daquelas que são as principais responsáveis pelos nascimentos num bairro que passa a contar com hospitais somente a partir da década de 1990. Lançando luzes ao entendimento de uma das problemáticas que a pesquisa levantou, a priori, sobre a remuneração dessas trabalhadoras, as memórias de Dona Penha sinalizam um ofício exercido por mulheres não remuneradas.

Um elemento bastante interessante e que diferencia esta de outras narrativas negras femininas, também, captadas ${ }^{7}$, é que dona Penha é a primeira entrevistada que não exerceu trabalho como empregada doméstica, a exemplo de sua mãe. Ela rompe com a hereditariedade do serviço doméstico, tão comum em histórias de mulheres negras no Brasil, exercendo a função de overloquista, e com um constructo discursivo que impunha [impõe] condições hegemônicas de

6 O Sr. Vicente também é um de nossos colaboradores. Sua entrevista faz parte da composição do texto dissertativo disponível em Silva (2015).

7 Para ter contato com outras entrevistas realizadas, ver em Silva (2015). 
inferioridade à mulher negra, desde a escravidão.

E é dentro desse universo de inferiorização permanente da mulher que Oliveira (2013) vai observar a cidade de São Paulo e do Rio de Janeiro a partir de dados trazidos pelo censo do IBGE $^{8}$ do ano de 2000, e nisso perceber a super-representação da mulher no setor de atividade do trabalhado doméstico. Essa atividade, que traz em seu cerne permanências do sistema escravocrata, e ainda enxerga uma mulher que é socializada para cuidar da casa, dos filhos, do marido, ou a mulher negra que é liberta para continuar cuidando, de outras casas, de outros filhos e de outros maridos.

A imagem privada da mulher negra é construída e naturalizada socialmente como a da doméstica, o que para Gonzalez (1983) significa a reafirmação de um dos lugares estipulados para ela no período escravocrata, a serviçal, a mucama: "Quanto à doméstica, ela nada mais é do que a mucama permitida, a da prestação de bens e serviços, ou seja, o burro de carga que carrega sua família e a dos outros nas costas" (IBIDEM, p. 230).

A mãe preta é outra figura desse universo colonial que se perpetuou e que está acorrentada ao núcleo familiar da elite branca, quando é ela quem cuidava dos filhos das mulheres brancas, desde o amamentar e até a fase adulta. Telles (2013) recompõe essa condição da empregada doméstica ao descrever as contingências enfrentadas por ex-escravas que se dedicavam a esse tipo de trabalho como profissão, e aborda, ainda, alguns aspectos da luta cotidiana dessas mulheres contra as estratégias de dominação dos patrões, que reafirmavam os valores burgueses escravocratas como o assédio moral, a violência sexual, os pagamentos compostos de ínfimos valores e as extensas horas de trabalho.

No pós-abolição, o serviço doméstico realizado por muitas mulheres negras transformou-as em arrimos de família num período em que os grupos populacionais negros sofriam com a exclusão no mercado de trabalho, consoante Andrews (1998). Mesmo diante desses elementos de opressão, essas mulheres compunham arranjos sociais e estratégias de sobrevivência que lhes permitiam resistir às condições impostas e promoverem, paulatinamente, mudanças sociais, como cita Telles (2013).

Eu fui uma criança muito triste, tem gente que não percebe, mas quem me conhece sabe. Eu acho que é devido a minha infância [...] que foi boa, mas teve muitos momentos tristes da nossa vida. Fome, sede, a minha mãe trabalhava e deixava a gente pequeno com meus avós para trabalhar. Ela trabalhava, mas a gente comia e bebia mal, e a gente mal vestia. Minhas

8 Instituto Brasileiro de Geografia e Estatística, órgão responsável pelo censo demográfico anual no Brasil. 
primas foram criadas junto com a gente, onde comia um, comia dez, comia vinte. A roupa que não servia, passava pra outro, um dependia do outro. Eu tive e não tive infância, já com 7 anos cozinhava para 12 pessoas no fogão de lenha. E se não cozinhasse o chicote estralava. Eu brincava bem de vez em quando, minha mãe não deixava a gente brincar.

De uma infância de dificuldades, onde o trabalho era a ordem primeira, dona Penha traz uma fala marcada por sentimentos de perdas e ausências. Criação comunitária, comida e roupas compartilhadas, brincadeiras substituídas por labor são elementos comuns que unem esta a todas as outras narrativas desta tipo de pesquisa, colocando em relevo a conjuntura em que grupos negros estavam inseridos no bairro, além de nos permitir, também, elucubrar sobre um modo de ser e estar no mundo ancorado em princípios fundamentais da filosofia africana, desdobrados enquanto experiência, conformando um eu comunitário. Fundamento este evidenciado nos textos de Serrano e Waldman (2007) e Appiah (1997) quando desdobram as famílias negro-africanas extensas como um conceito permeado por princípios fundamentais da filosofia africana, que permaneceu enquanto experiência e não se dissolveu no outro lado do Atlântico. São verdadeiras redes de solidariedade tecidas dentro das comunidades e que produzem uma espécie de estrutura social, tal qual as comunidades tradicionais de África nas quais a família é o suporte fundamental, o eu comunitário tem uma base arraigada na solidariedade. Nisso se funda um sentimento de pertencimento e identidade no qual todos são membros de uma única família, o que significa perpetuar uma África teimosa, desobediente e que se nega a morrer diante de um sistema que anseia por domesticar e canibalizar.

Criada em meio a esse movimento de vida, onde o que é de um é de todos, dona Penha, quando adulta, deparou-se com outras realidades e agruras que cercavam os grupos negros do bairro. Visitando muitas casas teve contato com situações de miserabilidade extrema e teve em si despertados sentimentos de solidariedade e o desejo de assistir sua comunidade. O pertencimento e a identidade vão reafirmar um eu participativo que, como cita Glissant (2005), se expressa e se completa no outro.

Acho que me envolvi com tudo isso por necessidade, e me envolvo até hoje. A gente vai se arranjando, um dá uma coisa, o outro dá outra, quando a gente vê, pronto! Já tem tudo! E aí a gente faz aquela festona, porque a união faz a força.

Outra parte da sua casa, também, se assemelha a um depósito cheio de pacotes de fraldas, brinquedos, roupas, diversos materiais que ela utiliza para desenvolver seus projetos comunitários. Pautando-se na força da comunhão, seus projetos caminham como um movimento integralizado, em 
que o ser humano é entendido enquanto um todo. Além de artigos como roupas, remédios, entrega de leite, verduras, campanha do quilo, entre outros, dona Penha também transita pela dimensão cultural, quando passou a organizar grandes festas juninas na Rua Antônio Thadeo 9 , quando algumas pessoas da comunidade ficavam responsáveis por uma barraca típica e o lucro era direcionado para o sustento de seus diversos projetos. Durante as festas havia muitas brincadeiras e diversas apresentações de grupos locais, ali se constituía um ponto de encontro de grupos negros e de toda a comunidade, quando era possível ter contato com expressões culturais e de sociabilização. Mesmo com toda a repercussão desses movimentos, com pesar, dona Penha nos conta que deixou de fazer a já tradicional festa junina de Guaianases por causa da instalação de uma linha de ônibus na respectiva rua, o que impossibilitava o seu fechamento durante as noites de festa. Em nome da modernidade, ações de melhorias urbanas que adentram, agora, os espaços periféricos, ainda expulsam a presença ou as manifestações negras dos territórios. Um passado tão presente ${ }^{10}$.

Outro movimento cultural constituído por dona Penha e sua comunidade é o Samba na Sombra, grupo que tem como presidente seu esposo, Faustino Rosa Severino. Constituído a partir de uma conversa entre amigos, trata-se de um grupo de sambistas negros que, sob a sombra de uma árvore na rua, passa todo o último domingo de cada mês entoando sambas, cantigas e memórias. Há uma rede de sociabilidades forjada nessas rodas de samba na sombra.

Naquela época começaram [a administração regional] a plantar árvores nas ruas. Plantaram muitas, mas com o tempo a maioria morreu ou foi arrancada para colocar asfalto, murar, construir outras coisas. Mas tinha uma, aquela que ficava na frente do bar que a gente se reunia, que nós cultivamos. Era onde se reuniam os amigos, era debaixo dela. Todas as outras cortaram, ela foi a única que sobreviveu. Eu acho que foi por causa da nossa força. Ali muitos cresceram, morreram, mas a gente continua debaixo da árvore. Essa árvore a gente adotou. Por isso todo mundo cuida dela.

A árvore tornou-se o símbolo desse movimento de expressão cultural negra, no qual a natureza faz parte de uma dimensão sobrenatural e também da vida humana constituindo uma relação ser humano-natureza, trata-se da representação de um elemento que, exposto a intempéries, se refaz constantemente para sobreviver. Nele é possível reconhecer vestígios de África no cotidiano desses negros e apontar para a capacidade de dialogar entre os tempos, a plasticidade de se mover, resistir, subverter de dentro para fora, numa verdadeira implosão da imagem que se queria, eurocêntrica, da cultura do espaço urbano. Ela passa a ser sentida e vivida pelo grupo, o que

9 Aqui, mais uma vez encontramos uma rua que evidencia a memória da presença italiana no bairro, nesse caso, da família Thadeo do ramo industrial oleiro.

10 Para ter contato com uma discussão mais larga sobre as ações de melhoramentos urbanos que expropriaram grupos negros de seus lugares de moradia, ver em Silva (2015). 
é muito significativo na medida em que há um reconhecimento da capacidade de resistência desses sujeitos da história ao lhe serem atribuídos papéis como o de abençoar vivências com a sua sombra e testemunhar chegadas e partidas deste mundo. Samba na sombra vai se constituindo como uma forma de produzir e expressar culturas negras, uma experiência comunitária produtora de ritmos, sons e memórias dentro do urbano. É mais do que uma reunião musical, é cultural.

Depois de ser batizada pela comunidade a árvore passou a se chamada de "Samba na Sombra". Em cumprimento ao ritual, toda a comunidade se achegou cantando o enredo feito em sua homenagem:

Menina dos olhos cheguei

Oh cheguei!!!

Me empresta sua sombra

Eu vi você crescer, me farto de tanto lazer

Junto com meu samba

Samba na sombra da árvore cantando poesia

O samba pede passagem com sua magia

Quem canta espalha o calor

O peito transborda de amor

No coração de um bamba

É tão feliz, quem canta samba

Samba um samba o ano inteiro

É partideiro, é raiz, quem canta

Seja no outono ou inverno

Primavera ou verão

Estaremos contigo, seja qual situação

Forte guerreira, não importa o tempo

Daqui pra frente tu serás inspiração

Pra nossa canção ${ }^{11}$

Demonstrando uma relação de afetividade entre a comunidade e a árvore, respeito, interdependência, fidelidade, reconhecimento e louvação, a música preparou o caminho para o derramar de águas em suas raízes, representando o alimento que dá a vida para que ela jamais morresse, depois cada um abraçou seu tronco e findou-se com todos fazendo a ela muitos pedidos. Mesmo assim, a festa não estaria completa, segundo dona Penha, se não fizessem festa.

Levamos tudo para a rua! Arroz, carne, saladas, tudo debaixo da árvore.

11 Música "Samba na Sombra" - Fonte de Inspiração de Faustino Rosa, Du Samba, D’Castro, Nenê Troca Letra e Conde da comunidade Samba na Sombra. Letra cedida por dona Penha Maria. 
Aqui é assim, todas as nossas comemorações, as festas, é tudo debaixo da árvore.

As festas da comunidade são compostas de um exagero estético na fartura de comidas, músicas, corpos, danças, sorrisos e alegrias que são compartilhados com os participantes diretos e todos que estiverem passando na rua.

Trazendo as angústias e alegrias dos grupos negros, as letras das músicas compostas pela comunidade do Samba na sombra se constituem a partir das experiências cotidianas, trata-se de uma rotina que inspira. Cantam o sol, o andar complicado da vida, o nascimento aguardado, as brigas da vizinha, a mulher do português, a poética da vida miúda, isto é, tiram do anonimato o sujeito de vida comum:

Eu travei, eu travei.

Num belo domingo de manhã

Com minha nega que armou uma mutreta pra mim não jogar

Não jogar, não jogar

Eu chorei, insisti, implorei

Nesse jogo eu não posso faltar ${ }^{12}$

Nossa amizade é tão ilustre

Nos reunimos e nós vamos festejar

Com harmonia, muita paz e saúde

Felicidade, deixa a vida te levar

Hoje a alegria está no ar $^{13}$

Em combate a essas experiências culturais, são expostos racismos e impedimentos balizados no discurso dominante, para subalternizar, impedir e silenciar as múltiplas resistências.

A gente por cantar ali sofremos muito racismo, principalmente da dona do depósito que fica do lado da árvore. Ela acha que as folhas que caem em seu telhado ou dentro do seu comércio atrapalham. Ela chamava os pais de família de vagabundo, brigava com todo mundo. Mas a gente contornou. E suas flores são amarela, aí fica tudinho amarelinha, e quando a gente tá ali debaixo cantando o samba dá aquela ventania, e as pétalas cai tudo em cima da gente. Aquele muro, também, atrás da árvore era pintado, tinha os desenhos das mesas, dos instrumentos, a sombra, mas aí veio aquela lei da prefeitura e tivemos que apagar tudo. Mas agora nós vamos fazer de novo, porque agora parece que pode.

12 Música "Eu travei”. Compositores: Samba na sombra, Raiz do Samba.

13 Música "Parabéns a você/Aniversário". Compositores: Samba na sombra, Raiz do Samba. 
Para a negativa se encontrou um caminho, os impedimentos podem ser combatidos e a hostilidade pode ser contornada, conquistada, porque vale a pena, a vida vale a pena, e, segundo dona Penha:

Às vezes as pessoas me dizem que vão largar o movimento, mas eu não vou largar! O samba não pode parar! [...]

Eu com 7 anos de idade já saía na rua com os blocos de carnaval, meus tios, meus irmãos, meus parentes tudinho. Eu era pequenininha, minha mãe fazia minha fantasia com papel crepom e saíamos todos bonitos no cordão. Esse meu samba veio no sangue, na veia, desde criança. Meu pai tinha um conjunto de pagode e tocava pandeiro. A gente tinha aquelas danças nossas rituais, que a gente fazia com os cantos que meu pai fazia com o pandeiro dele de couro de carneiro, e ali já começava a festa. E ele aprendeu com o pai dele, lá em Minas Gerais. Minha família é só negros! Meus filhos foram tudo criados no partido, eu sou partideira. Eu toco timba e cuíca. Sabe quando você chega na avenida, por mais que a gente desfila só 40 minutos, mas para nós é uma felicidade.

A narrativa de dona Penha nos revela um papel de liderança cultural, que foi assumido também por algumas mulheres negras ligadas ao samba paulistano. Figuras femininas que assumiram papéis protagonistas dentro das redes negras de sociabilidades constituídas nos movimentos musicais e no universo cultural negro, como cita Azevedo (2015). A mesma mulher negra, comumente representada pela figura da subalternidade, o objeto a ser consumido, a serviçal, como cita Gonçalves (2006), apropria-se de funções vitais para os grupos e suas memórias. Apaixonada pela vida, pela comunidade, pelo outro, essa líder se declara a um samba forte de dimensões históricas, ressonância direta na diáspora, ancestralidade, que inibe a morte da existência e permite que ela se conecte com o sensível, o tempo e com suas verdades mais profundas, o sentido de ser e estar no mundo. Para dona Penha: “O samba não morre! Sem samba eu não vivo! Se não tiver um pagode fico doente! O samba é tudo na minha vida!”.

\section{Considerações finais}

$\mathrm{Na}$ contramão de uma produção historiográfica dominante, vasta, extremamente popularizada e introjetada no imaginário coletivo, entendeu-se a importância de que novos pesquisadores se lancem em perceber e refletir sobre as ausências produzidas. Nessa perspectiva, encontrou-se aporte no conceito de micro-Áfricas e na metodologia da história oral para poder captar permanências e resistências das culturas negras no bairro de Guaianases e faze-las visíveis à comunidade acadêmica.

A narrativa de dona Penha Maria Lima Severino nos proporcionou pensar, adentrar e reconhecer as práticas engendradas por ela e sua comunidade como ações que descontroem 
retoricas universalistas, valorizam o local, confrontam epistemologias consagradas e autorrepresentam as culturas negras, constituindo um lugar de não apagamento das memórias negras e que promove o pertencimento da comunidade com o território, às micro-Áfricas.

Mesmo sendo a história de vida constituída de traços biográficos a narrativa de dona Penha esta para além da expressão única de fatos particulares de sua trajetória. Falando de si, ela fala da comunidade, porque quando acessa suas histórias reverbera nos outros, por que ela fala de uma existência. É um individuo comunitário de histórias compartilhadas. São culturas que não se deixaram apagar, são histórias que não se querem escondidas e que não se curvam aos ditames de ideologias expropriatórias, numa perspectiva emancipatória e de resistência.

\section{Referências Bibliográficas:}

Geral

ANDREWS, George Reid. Negros e brancos em São Paulo (1888 -1988). Bauru/SP: EDUCS, 1998.

ANTONACCI, Maria Antonieta. Memórias ancoradas em corpos negros. São Paulo: EDUC, 2013.

APPIAH, Kwame Anthony. Na casa de meu pai: A África na filosofia da cultura. Rio de Janeiro: Contraponto, 1997.

AZEVEDO, Amailton Magno. A memória musical de Geraldo Filme: Os sambas e as micro-Áfricas em São Paulo. São Paulo: Faculdade de História. Pontifícia Universidade Católica de São Paulo, 2006. Tese de doutorado em História, 242 p.

. Mulheres negras do samba paulista. In: MATOS, Maria Izilda Santos; BRANCO, Pedro Vilarinho Castelo (org). Cultura, corpo e educação: diálogos de gênero. São Paulo: Editora Intermeios, 2015.

BOSI, Ecléa. Memória e sociedade: Lembranças de velhos. São Paulo: Companhia das Letras, 1994.

CERTEAU, Michel de. A escrita da história. Rio de Janeiro: Forense Universitária, 1982.

. A invenção do cotidiano: Artes de fazer. v.1. Petrópolis: Editora Vozes, 1998.

D’ALESSIO, Marcia M. Memória e historiografia: limites e possibilidades de uma aproximação. História Oral. Revista da Associação Brasileira de História Oral, n.4, jun. 2001. p. 55-71 Disponível em: http://revista.historiaoral.org.br/index.php? journal=rho\&page=article\&op=view\&path\%5B\%5D=35. Acesso em: 14 set. 2015 .

GONÇALVES, Ana Maria. Um defeito de cor. São Paulo: Record, 2006.

GONZALEZ, Lélia. Racismo e sexismo na cultura brasileira. In: SILVA, Luiz A. M. et al. Ciências Sociais Hoje, ANPOCS, n. 2, 1983, p. 223-244.

GLISSANT, Édoard. Por uma poética da diversidade. Juiz de Fora, Minas Gerais: Ed. UFJF, 2005.

HAMPATÉ BÂ, Amadou. A tradição viva. In: História Geral da África I: Metodologia e PréHistória da África. $2^{a}$ ed. rev. Ed. Joseph Ki-Zerbo. Brasília: UNESCO, 2010.

HALL, Stuart. Da diáspora. Belo Horizonte: UFMG, 2013. 
HOLANDA, Sérgio Buarque de. Raízes do Brasil. 26a ed. São Paulo: Cia das Letras, 1995. LE GOFF, Jacques. História e memória. Campinas/SP: Editora da Unicamp, 2000.

MATTOS, Hebe. et al. Por uma história pública dos africanos escravizados no Brasil. Estud. Hist. (Rio J.), v. 27, $\mathrm{n}^{\mathrm{o}}$ 54, Rio de Janeiro, Jul/Dez, 2014. Disponível em: http://www.scielo.br/scielo.php?pid=S0103-21862014000200255\&script=sci_arttext. Acesso em: 12 set. 2015.

MEIHY, J. C. S. B. Manual de história oral. São Paulo: Loyola, 2005.

OLIVEIRA, Reinaldo José de. Interfaces entre as desigualdades urbanas e as desigualdades raciais no Brasil: observações sobre o Rio de Janeiro e São Paulo. In: negro no Brasil: Cidadania e território. São Paulo: Alameda, 2013, p. 43-94.

PORTELLI, Alessandro. Sonhos ucrônicos: memórias e possíveis mundos dos trabalhadores. Projeto História. São Paulo, v. 10, dez/1993, p. 41-59.

RISÉRIO, Antônio. A utopia brasileira e os movimentos negros. São Paulo: Editora 34, 2007.

SERRANO, Carlos; WALDMAN, Maurício. Memória d'África: a temática africana em sala de aula. São Paulo: Cortez, 2007.

SILVA, Sheila Alice G. da. Negros em Guaianases: Cultura e Memória. São Paulo: Faculdade de História. Pontifícia Universidade Católica de São Paulo, 2015. Dissertação de mestrado em História, 146 p.

SOUZA, João Carlos de. Na luta por habitação: a construção de novos valores. São Paulo: EDUC, 1995.

TELLES, Lorena Féres da Silva. Libertas entre sobrados: Mulheres negras e trabalho doméstico em São Paulo (1880-1920). São Paulo: Alameda, 2013.

VANSINA, J. A tradição oral e sua metodologia. In: KI-ZERBO (coord.). História Geral da África I. Metodologia e pré-história da África. São Paulo: Ática; Paris: UNESCO, 1982, p. 157179.

\section{Entrevistas}

Penha Maria Lima Severino, overloquista, cofundadora do grupo Samba na Sombra e da Escola de Samba homônima, moradora do bairro de Guaianases. Entrevista concedida à autora em $09 / 10 / 2015$.

\section{Recebido em 28/05/2016 - Aceito em 27/07/ 2016.}

